\title{
The Politicisation of China's Law-Enforcement and Judicial Apparatus
}

\section{Willy Wo-Lap Lam}

\section{(2) OpenEdition \\ 12 Journals}

Electronic version

URL: http://journals.openedition.org/chinaperspectives/4805

DOI: 10.4000/chinaperspectives.4805

ISSN: 1996-4617

\section{Publisher}

Centre d'étude français sur la Chine contemporaine

\section{Printed version}

Date of publication: 1 June 2009

Number of pages: $42-51$

ISSN: 2070-3449

\section{Electronic reference}

Willy Wo-Lap Lam, «The Politicisation of China's Law-Enforcement and Judicial Apparatus », China Perspectives [Online], 2009/2 | 2009, Online since 01 June 2011, connection on 28 October 2019. URL : http://journals.openedition.org/chinaperspectives/4805; DOI : 10.4000/chinaperspectives.4805

This text was automatically generated on 28 October 2019

(C) All rights reserved 


\title{
The Politicisation of China's Law- Enforcement and Judicial Apparatus
}

\author{
Willy Wo-Lap Lam
}

\section{ABSTRACTS}

The Chinese Communist Party has politicised the judicial and law-enforcement apparatus despite Beijing's avowed commitment to global norms. This paper shows how, in the wake of the 4 June 1989 crackdown, the CCP leadership enhanced its control over the courts and procuratorates so as to boost its capacity to punish dissidents, separatists, and other destabilising elements. Despite President Hu Jintao's slogan of "running the country according to law," the prospect for rule of law and judicial independence remains illusory.

\section{AUTHOR}

\section{WILLY WO-LAP LAM}

Professor of Chinese Studies, Akita International University, Japan and Adjunct Professor of History at the Chinese University of Hong Kong. 